\title{
CONDUIT FLOW IN THE CAMBRIAN LONE ROCK FORMATION, SOUTHEAST MINNESOTA, U.S.A.
}

John D. Barry

Minnesota Department of Natural Resources, Division of Ecological \& Water Resources, 500 Lafayette Road, St.Paul, MN 55155-4040, U.S.A., john.barry@state.mn.us

Jeffrey A. Green

Minnesota Department of Natural Resources, Division of Ecological \& Water Resources, 3555 9th St. NW Suite 350, Rochester, MN, U.S.A., 55901, jeff.green@state.mn.us

Julia R. Steenberg

Minnesota Geological Survey, 2609 Territorial Road, St.Paul, MN 55114, U.S.A., and01006@umn.edu

\begin{abstract}
The karst lands of southeast Minnesota contain more than one hundred trout streams that receive perennial discharge from Paleozoic bedrock springs. Several of the Paleozoic bedrock units that provide discharge are karst aquifers. Field investigations into the flow characteristics of these formations have been conducted using fluorescent dyes to map groundwater springsheds and characterize groundwater flow velocities for use in water resource protection.
\end{abstract}

Recent field work has focused on the Cambrian Lone Rock Formation, a siliciclastic unit consisting of very finegrained sandstone and siltstone with minor beds of shale and dolostone. The formation is mapped within tributary valleys of the Mississippi River throughout southeastern Minnesota and southwestern Wisconsin. Overlying the Lone Rock is the Cambrian St. Lawrence Formation. Over a dozen streams have been observed to disappear into stream sinks where the upper St. Lawrence is the bedrock unit closest to the land surface. At three of these sinking stream locations, dye was recovered emanating from springs located in the basal St. Lawrence or from springs located in two distinct zones in the Lone Rock. Dye-breakthrough velocities calculated using passive charcoal detectors ranged between 21-214 meters/day at one location and 88-153 meters/day at another. At a third site, automatic water samplers were placed at a spring that had been previously demonstrated to be connected to a St. Lawrence stream sink through dye tracing. In that trace, an eight-hour sampling frequency determined the dye-breakthrough velocity was 314 meters/day.

Based on outcrop and borehole observations in Minnesota, secondary pore networks in siliciclastic- dominated units generally have bedding-parallel and vertically oriented apertures less than a few centimeters. The process by which the bedding-parallel secondary pore networks form remains obscure; some appear to be mechanically developed. However, interstitial carbonate cement within these units leads to the possibility of dissolution being a minor factor in the formation's groundwater flow characteristics. These dye traces were conducted at three different sites across a twenty-three kilometer distance and are evidence that the siliciclastic Lone Rock Formation has a conduit-flow component similar to that found in carbonate karst aquifers.

\section{Introduction}

Southeastern Minnesota is underlain by a sequence of Cambrian to Devonian sedimentary bedrock layers that were deposited in a broad structural depression known as the Hollandale Embayment. In general, the older rocks are dominated by siliciclastic materials and the younger rocks dominated by carbonates (Mossler, 2008). A hydrogeologic framework that describes four prominent karst systems for southeastern Minnesota (Runkel et al., 2013) is based largely on the work of Alexander and Lively (1995), Alexander et al. (1996), and Green et al. $(1997,2002)$. These include the Devonian Cedar Valley, the Upper Ordovician Galena-Spillville, the Upper Ordovician Platteville Formation, and the Lower Ordovician Prairie du Chien Group.

The karst systems defined in the framework meet the traditional criteria associated with karst, "an integrated mass-transfer system in soluble rocks with a permeability structure dominated by conduits dissolved from the rock and organized to facilitate the circulation of fluid" (Klimchouk and Ford, 2000). 
In the last seven years, investigators in southeastern Minnesota have been characterizing sinking streams and rapid flow in two of the siliciclastic dominated formations of the Cambrian system: the St. Lawrence and Lone Rock Formation (Green et al., 2008, 2012). The St. Lawrence consists of well-cemented, thin-to-medium beds of siltstone, dolomitic siltstone, very fine-grained sandstone and shale. The Lone Rock, a formation within the Tunnel City Group, is mostly composed of a fine-grained sandstone and siltstone with interbedded shale and dolostone (Mossler, 2008). Groundwater flow velocities of 35-750 meters/day (115-2460 feet/day) recorded in many dye traces through these units are consistent with conduit flow. However, the lack of large conduit networks in outcrop and borehole observations makes classifying these formations as karst tenuous. Characterization of flow through tracing and breakthrough curves for these units is more consistent with the definition of pseudokarst, "landscapes with morphologies resembling karst, and/or may have a predominance of subsurface drainage through conduit type voids, but lack the element of long-term evolution by solution and physical erosion" (Kempe and Halliday, 1997). Recent work has shown that the millimeter-to-centimeter-sized, beddingparallel apertures in siliciclastic bedrock of southeastern Minnesota are connected through an anastomosing network of apertures, clustered along discrete $(<2 \mathrm{~m})$ stratigraphic intervals and found at depths exceeding 200 meters (Runkel et al., 2015). The apertures are more limited in size than in karstic carbonate rock and are commonly associated with distorted bedding interpreted to reflect dewatering features that occurred shortly after burial when the rock was only partially lithified. Therefore, these voids are unlikely to be primarily the result of dissolution as karst is traditionally defined (Stewart et al., 2012 and Runkel et al., 2015).

This paper focuses on the geologic and hydrogeologic setting and results of three recent traces in these siliciclastic units conducted in Houston and Winona counties (Figure 1).

\section{Geologic and Hydrogeologic Setting of Dye Traces}

In Houston and Winona counties, bedrock units from the Upper Cambrian through the Upper Ordovician are generally within 15 meters of the land surface and are capped by unconsolidated sediments such as loess, sand, and colluvium (Steenberg, 2014ab; Lusardi et al.,

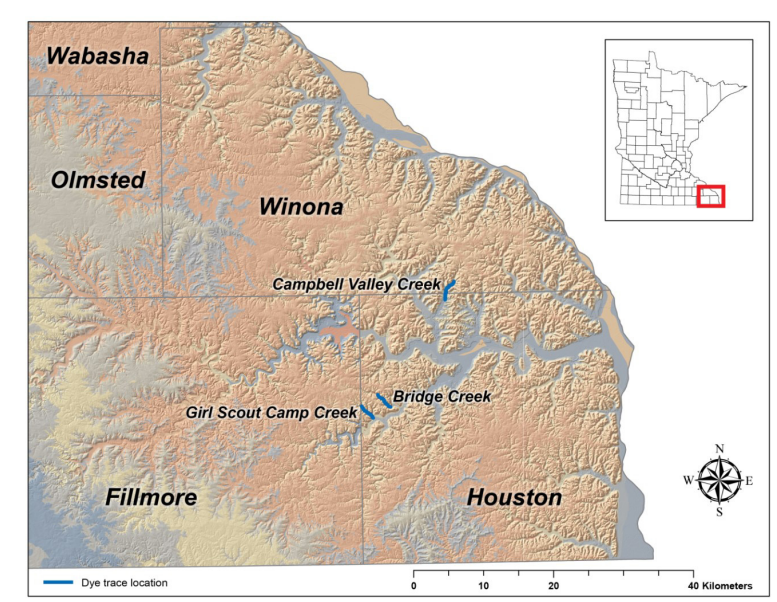

Figure 1. Regional geologic setting of Paleozoic rocks in southeast Minnesota and locations of the dye traces presented in this report. Upper Devonian units are depicted with blue hues in the southwest corner of map. The Ordovician units are depicted with orange hues. Lower Cambrian units are depicted with gray and light brown hues in eastern portion of map. Geologic map from Runkel et al., 2013.

2014). The topography is dominated by a broad plateau of resistant dolostone of the Ordovician Prairie du Chien Group (OPDC). The OPDC is one of the four karst systems identified in southeastern Minnesota and contains many solution-enhanced fractures and cavities such as sinkholes, large conduits, and caves. A region-wide high permeability zone is located at an unconformity between the Shakopee and Oneota Formations of the OPDC (Runkel et al., 2003; Tipping et al., 2006). Catastrophic failures of sewage treatment ponds have occurred where this high permeability zone is close to the land surface (Alexander et al., 2013). The resistant dolostone layer that dominates the plateau is dissected by numerous narrow valleys, especially in the eastern region of the counties near the Mississippi River. In general, the stratigraphy underlying the OPDC is dominated by more easily weathered sandstone, siltstone, and shale layers that are prevalent on slopes and valley floors. It is in these non-carbonate layers that the focus of this report occurs.

Recent work characterizing fracture characteristics at outcrops of the lower Jordan Sandstone through upper Tunnel City Group in the Twin Cities metropolitan area shows that vertical to subvertical fractures tend to preferentially terminate at specific bedding contacts (Runkel et al., 2014). Changes in lithology at these interfaces are also likely responsible for large head 
differences noted at a recently installed multilevel groundwater monitoring multiport system that intersects the same layers that were characterized in outcrop (Runkel et al., 2014).

In deep bedrock settings, the Cambrian St. Lawrence Formation (CSTL) has a low bulk vertical conductivity and a high bulk horizontal conductivity, demonstrating a marked anisotropy (Runkel et al., 2003). The low bulk vertical hydraulic conductivity for the CSTL in deep settings has influenced the general understanding of the hydrostratigraphic properties of the unit and it is generally thought of as a regional aquitard. Characterization of the CSTL as an aquitard is included in the Minnesota Well Rules handbook where it specifically states that "a stratum at least 10 feet $[3.05 \mathrm{~m}]$ in vertical thickness of the St. Lawrence" is a confining layer (Minn. Dept. of Health, 2011). In southeastern Minnesota where bedrock is shallow and is cut by deeply incised valleys, the CSTL can have highly variable bulk vertical conductivity and high bulk horizontal conductivity (Runkel et al., 2003; Green et al., 2008; Green et al., 2012). In proximity to deeply incised valleys, the ability of the CSTL to behave as an aquitard is tenuous.

A geologic column for Houston County (Figure 2) shows lithostratigraphic and generalized hydrostratigraphic properties for each of the units (Steenberg, 2014a). Hydrostratigraphic attributes have been generalized into either aquifer or aquitard based on their relative permeability. Layers assigned as aquifers are permeable and easily transmit water through porous media, fractures or conduits. Layers assigned aquitard have lower permeability that vertically retards flow, effectively hydraulically separating aquifer layers. However, layers designated as aquitards may contain high permeability bedding plane fractures conductive enough to yield large quantities of water.

\section{Methods}

The dye traces and geochemical data presented in this report were conducted to further delineate springsheds in the area, characterize sinking streams in the Cambrian St. Lawrence Formation, and describe surface water to groundwater interactions in the counties. Traces focused on locations where surface water was known to be sinking and where local landowner permission was granted. Fluorescent dye was poured into a sinking stream or sinkhole. From there its flow through a conduit system

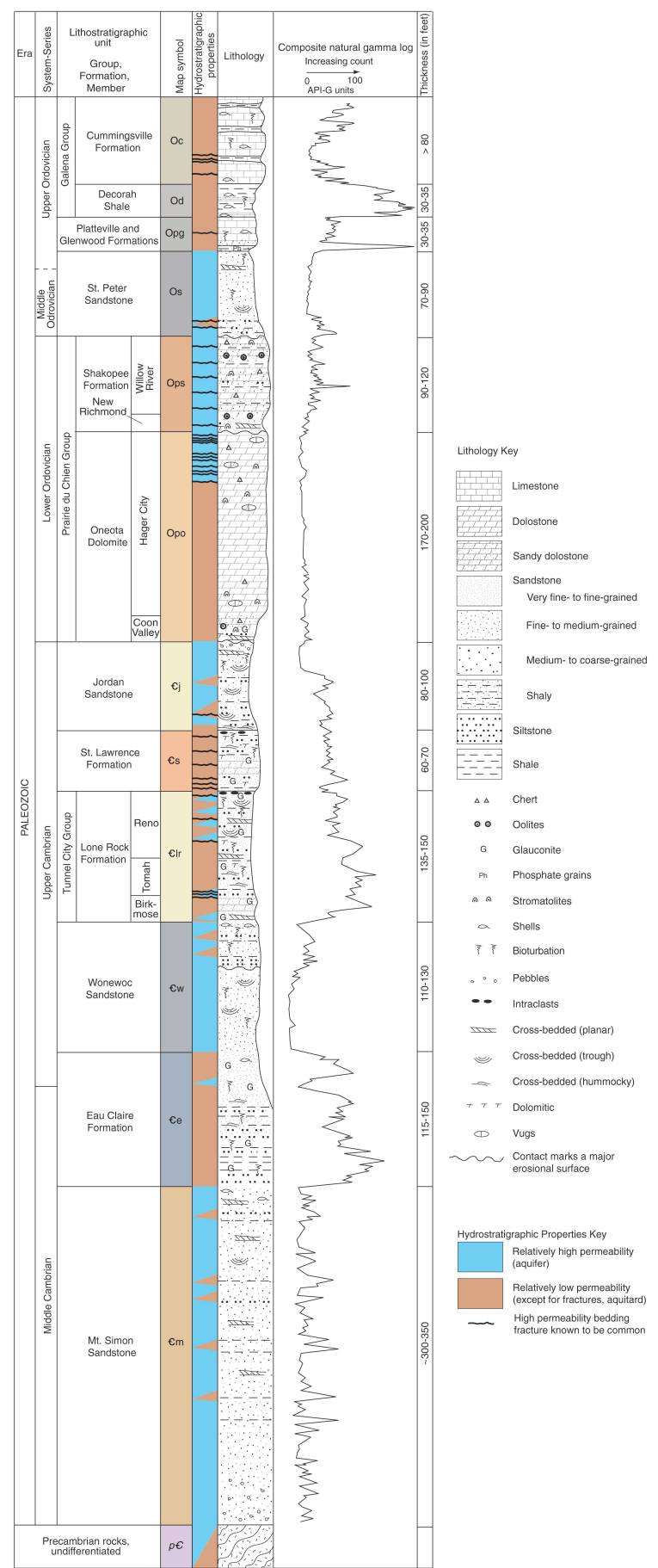

Figure 2. Geologic and hydrogeologic attributes of Paleozoic rocks in southeastern Minnesota. Modified from Steenberg, 2014a.

was timed and mapped based on when and where it reemerged at a spring. Dye was recovered through water grab samples, passive dye receptors (packets of coconut charcoal informally referred to as "bugs") and, for the Bridge Creek trace, an automatic water sampling device. 
Analyses of water samples and charcoal detectors were performed at the University of Minnesota Department of Earth Sciences Hydrochemistry Laboratory using a Shimadzu RF5000 scanning spectrofluorometer and PeakFit software. Anions were analyzed for additional direct water samples from springs and streams for two of the traces using a Dionex ICS-2000 Ion Chromatography System. These samples were collected under base flow conditions to further characterize the hydrologic system. Stratigraphic interpretations of spring positions are based on a combination of field outcrop examination and correlations to water well records from the County Well Index (Bauer and Chandler, 2014).

\section{Dye Tracing Results Bridge Creek}

Bridge Creek in Yucatan Township, Minnesota was the site of dye traces in 2012 and 2013 (Figure 3). It receives discharge from a number of springs that emanate from the basal Jordan Sandstone. The 2012 trace consisted of the introduction of 1.104 kilograms $(\mathrm{kg}$.) of Eosin dye into a discrete sinking stream point on Bridge Creek (MN28:B00006) located in the CSTL. Stream discharge at the time was estimated to be $0.008-0.014$ cubic meters per second (0.3-0.5 cubic feet per second).

Eosin dye was detected at levels high enough for positive quantification at a number of sampling sites. Dye was detected at Rostvold Spring which emanates from the Lone Rock (CTLR) 20 - 28 days later. Assuming a straight-line distance from the stream sink (MN28:B00006) to Rostvold Spring, this translates to a minimum peak groundwater velocity ranging from roughly 146 to 205 meters/day (480 ft/day to $670 \mathrm{ft} /$ day). Dye was also detected in charcoal receptors at the Bridge Creek Outlet, the Frauenkron Crossing, the Frauenkron well, and the Bolster spring pond, all within the CTLR. Dye detection for the Frauenkron well was determined using passive detectors placed in their toilet tank reservoir. The well owners had previously stopped using the well for potable water after having multiple gastrointestinal issues. The well has since

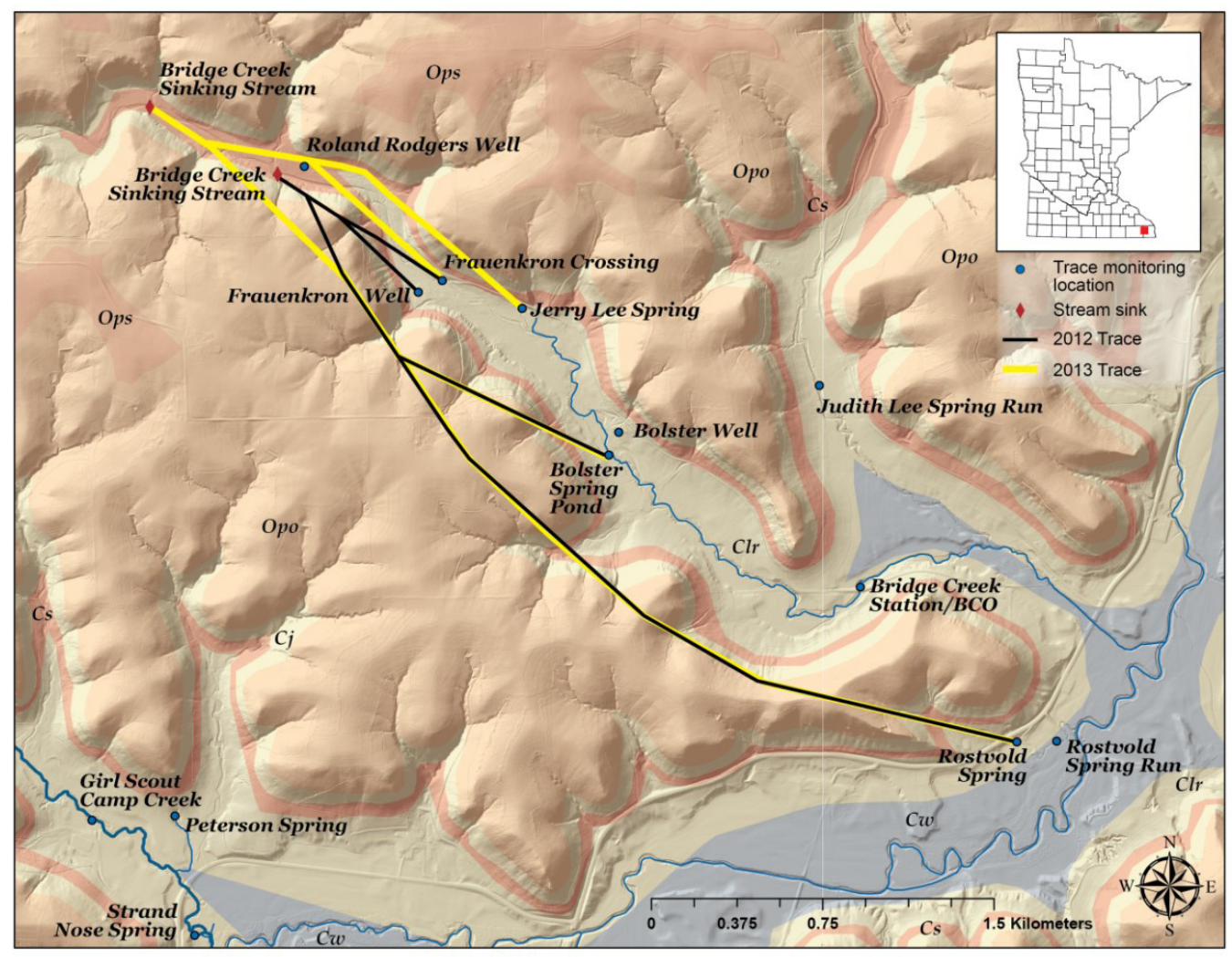

Figure 3. Bridge Creek site sampling locations and dye flow vectors for 2012-2013. Dye flow vectors for the 2012 trace are shown in black. Dye flow vectors for the 2013 trace are shown in yellow. See Figure 2 for definition of map symbols. Note: trace vectors not drawn to dye receptor locations that integrate upstream waters. Geologic map from Runkel et al., 2013. 
been abandoned and replaced. Borehole geophysics conducted during well abandonment found evidence of fracture flow in the middle to upper Tunnel City from the caliper and fluid resistivity logs.

The year following the 2012 Bridge Creek trace, 24.1 centimeters (9.5 inches) of rain fell in the Bridge Creek watershed between June 21 and 25, 2013. Overland stream flow during this event heavily altered the geomorphology of Bridge Creek, causing large shifts in the stream's thalweg. Following the precipitation event, surface water was no longer making it down the valley and reconnaissance was conducted to determine where the stream was losing water. Surface water was found to be sinking into a location roughly 610 meters (2000 feet) upstream from MN28:B00006 in the CSTL. A stream sink had previously been speculated to be in this general vicinity based on black and white aerial imagery from 1991. An additional trace was conducted on September 12, 2013 because of this dramatic shift in the sinking stream location. The second dye trace introduced $1.073 \mathrm{~kg}$ of Uranine dye into a sinking pool and discrete sinking stream point on Bridge Creek (MN28:B00005) (Figure 3).

Stream discharge at the time was estimated to be 0.003 cubic meters per second ( 0.1 cubic feet per second). Passive receptors and three automatic samplers programmed to sample at eight hour intervals were deployed during the first seventy days of the 2013 trace. Automatic samplers are ideal for characterizing dye-breakthrough curves (Figure 4). Uranine dye was detected at levels high enough for positive identification at both the passive and active sampling sites. Uranine dye was detected in the automatic samplers at Rostvold Spring (CTLR) 15 days later. Assuming a straight line distance from the stream sink (MN28:B00005) to Rostvold Spring, this translates to a minimum peak groundwater velocity of roughly 314 meters/day (1,031 ft/day). This velocity is consistent with previous traces in the St. Lawrence (Green et al., 2012). Dye was also detected in charcoal detectors at Frauenkron Crossing, Jerry Lee Spring, and Bolster Pond Spring Outlet. Eosin dye used in the 2012 trace was additionally detected a year later during the 2013 trace at Rostvold Spring, Bridge Creek Outlet, Jerry Lee Spring, and Frauenkron Crossing. The long tail on dye recovery observed in this trace is consistent with dye recovery in previous St. Lawrence traces (Green et al., 2008, 2012).

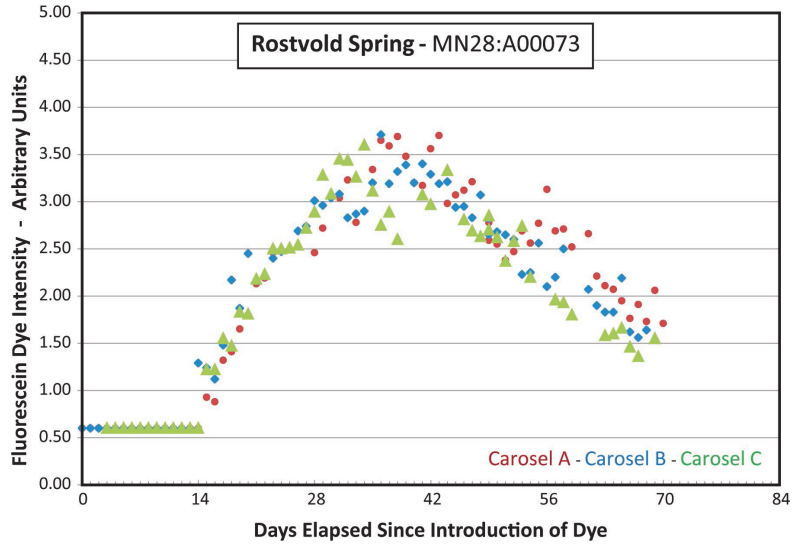

Figure 4. Breakthrough curve for the 2013 Bridge Creek dye trace. Dye was introduced into stream sink (28:B00005) located roughly 4,716 meters (15,469 feet) in a straight line distance from Rostvold Spring. Dye arrived at the spring 15 days after input.

\section{Girl Scout Camp Creek}

The Girl Scout Camp Creek trace was run synchronously with the 2013 Bridge Creek trace. Although not fieldchecked, the creek is assumed to begin at springs emanating from the Jordan Sandstone. The trace was initiated on September 12, 2013, with the introduction of $1.057 \mathrm{~kg}$ of Rhodamine WT dye into a sinking pool in the CSTL (MN28:B00004) located in a tributary valley of Girl Scout Camp Creek. Stream discharge at the time was estimated to be 0.007 cubic meters per second $(0.25$ cubic feet per second).

Rhodamine WT dye was detected at levels high enough for positive identification at multiple sampling sites including the Whispering Hills Spring (CTLR) within 15 days and at the Peterson Spring (CTLR) within 14 days (Figure 5). An early breakthrough time for the St. Lawrence "nose" spring was not recorded due to mammals destroying passive detectors early in the trace. In southeastern Minnesota, numerous CSTL and CTLR springs resurge at promontory points at the toe of the slope where incised valleys meet; they are informally referred to as "nose" springs in this paper. Dye was recovered at the passive detectors at the CSTL "nose" spring between September 27 and October 17.

Assuming a straight line distance from stream sink (MN28:B00004) to Whispering Hills Spring, this translates to a minimum peak groundwater velocity of roughly 88 meters/day (290 ft/day) and to Peterson Spring, a minimum peak groundwater velocity of roughly 153 meters/day (503 ft/day). 


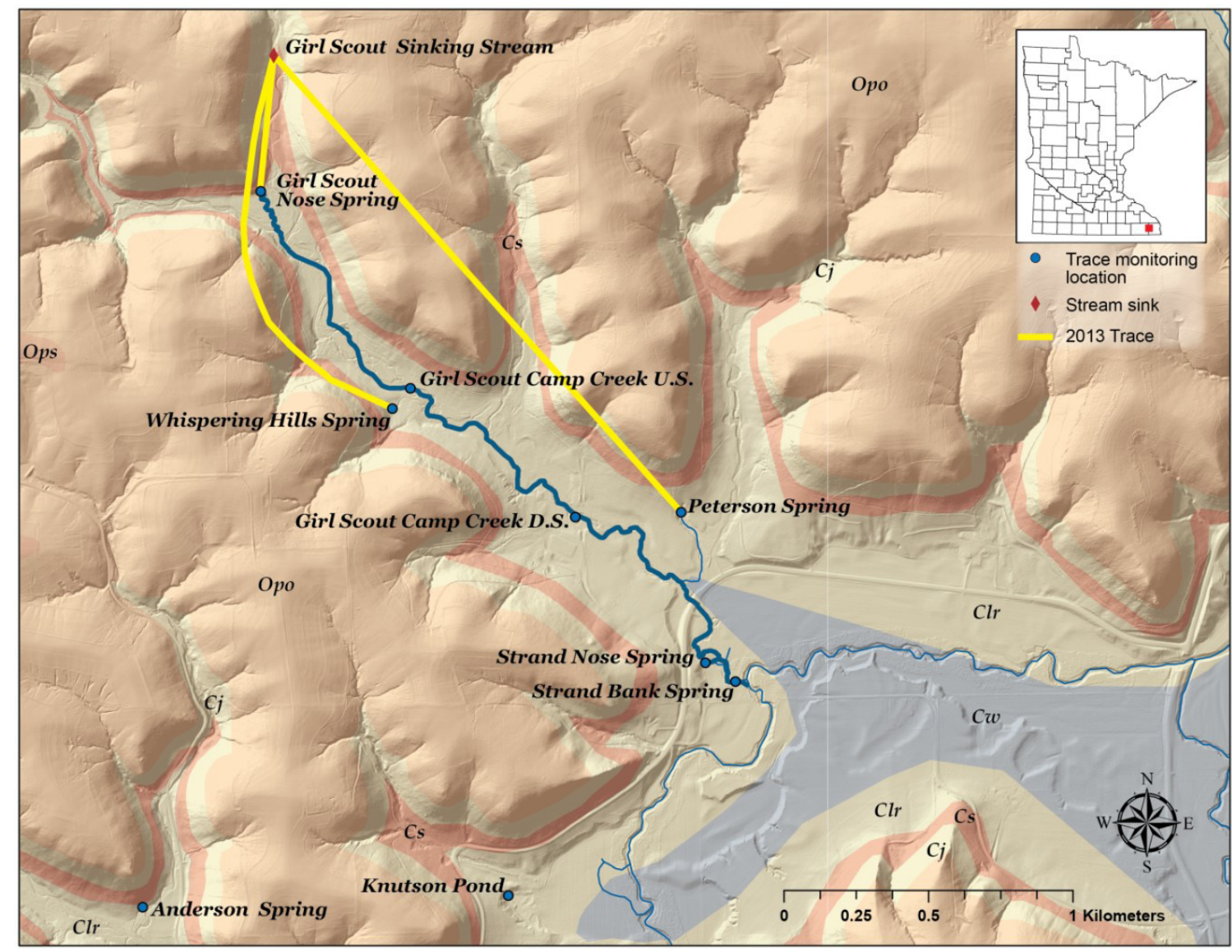

Figure 5. 2013 Girl Scout Camp Creek site sampling locations and dye flow vectors (yellow). Note: trace vectors not drawn to dye receptor locations that integrate upstream waters. Geologic map from Runkel et al., 2013. See Figure 2 for definition of map symbols.

The locations of the Strand nose spring and bank spring were not known during the active monitoring stage of this trace and they were not visited unit March 4, 2014. At that point passive dye receptors were deployed and water chemistry was collected. Passive detectors showed no evidence of dye at the Strand springs.

\section{Campbell Valley Creek}

Dye traces were conducted on Campbell Valley Creek in Pleasant Hill Township, Minnesota in 2012 and 2013. Campbell Valley Creek starts at a spring that emanates from the basal Jordan Sandstone and sinks within 50 meters (164 feet) into the upper St. Lawrence Formation (Figure 6). Farther down the valley, water resurges at two small perennial St. Lawrence Formation springs. The Campbell Valley Creek also sinks into the Lone Rock Formation within 10 meters (32 feet) downstream and resurges at the basal Lone Rock Formation farther down the valley.
The 2012 trace consisted of the introduction of $1.166 \mathrm{~kg}$ of Uranine dye into a discrete sinking stream point on upper Campbell Valley Creek (MN85:B0020) located in the CSTL. Stream discharge at the time was estimated to be $0.00006-0.0003$ cubic meters per second $(0.002-$ 0.011 cubic feet per second). Uranine dye was detected at levels high enough for positive identification at multiple sampling sites including the Barnhardt 1 and 2 springs (CSTL) and Pagel's Big Spring and Power Spring (CTLR). Assuming a straight line distance from the stream sink (MN85:B0020) to the Barnhardt springs, the minimum peak groundwater velocity is roughly 21 meters/day (69 ft/day). Assuming a straight line distance from the stream sink (MN85:B0020) to Pagel's springs, the minimum peak groundwater velocity ranges between 55 and 214 meters/day (180 $\mathrm{ft} /$ day-702 ft/day). Despite being located within the lowermost Lone Rock Formation, these velocities are still consistent with previous traces in the St. Lawrence and uppermost Lone Rock Formation. 


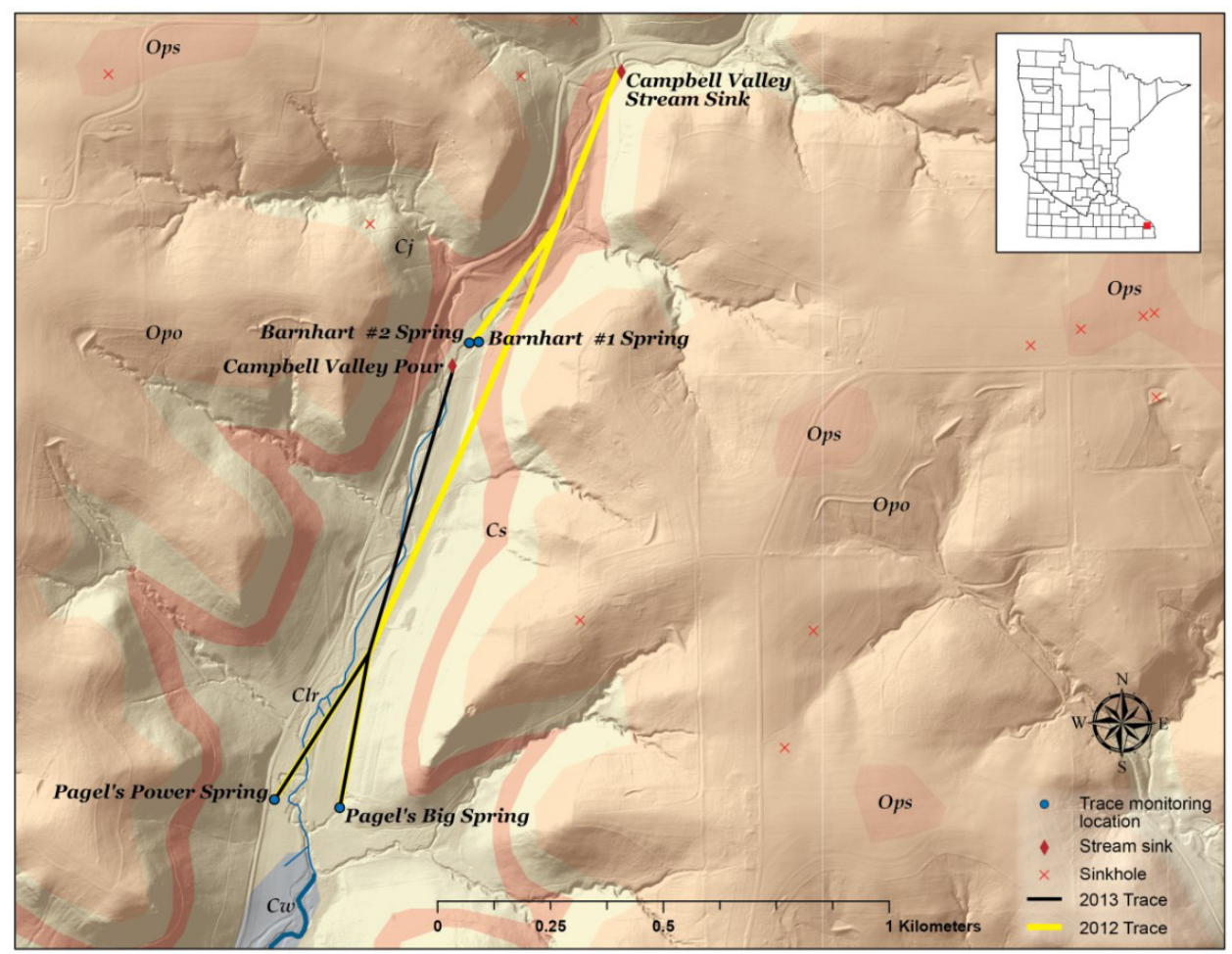

Figure 6. 2012-2013 Campbell Valley Creek site sampling locations and dye flow vectors. Dye flow vectors for the 2012 trace are shown in yellow. Dye flow vectors for the 2013 trace are shown in black. See Figure 2 for definition of map symbols. Note: trace vectors not drawn to dye receptor locations that integrate upstream waters. Geologic map from Runkel et al., 2013.

The 2013 trace consisted of the introduction of 1.843 $\mathrm{kg}$ of Rhodamine WT dye into the creek upstream from the stratigraphically lower sinking stream reach located in the Lone Rock Formation (MN85:X0037). Stream discharge at the time was estimated to be $0.008-0.014$ cubic meters per second $(0.3-0.5$ cubic feet per second). The dye input points and receptor locations for both the 2012 and 2013 traces are shown in Figure 6. Dyes were detected at levels high enough for positive quantification at Pagel's Big Spring and Pagel's Power Spring. Minimum peak groundwater velocity to the Pagel Springs is roughly 33 meters/ day (108 ft/day), assuming a straight line distance from the sinking stream reach (MN85:X0037) to the springs.

\section{Geochemical Results and Discussion}

Elevated levels of nitrate and chloride can be used as geochemical indicators of recent human influence on groundwater. They can be attributed to the application of road salts, the use of water softeners, and fertilizer application. We used the following classification scheme to assign the term elevated to these anion species.
Nitrate concentrations greater than 1 part per million (ppm) are greater than background conditions and possibly indicate that an aquifer has been impacted by activities on the land surface (Minn. Dept. of Health, 1998 and Wilson, 2012). Nitrate concentrations greater than $3 \mathrm{ppm}$ indicates that an aquifer has been impacted by activities on the land surface (Minn. Dept. of Health, 1998).

Chloride concentrations of greater than $5 \mathrm{ppm}$ can also be used to indicate that an aquifer has been impacted by activities on the land surface. Multiple investigators have used $\mathrm{Cl} / \mathrm{Br}$ ratios to identify chloride sources to groundwater (Davis et al., 1998; Panno et al., 2006). In general, samples with chloride-to-bromide ratios above 300 are waters that have been elevated by human activity.

Anion chemistry collected during the Bridge Creek and Girl Scout Creek dye traces show elevated levels of nitrate, chloride, and chloride-to-bromide ratios in the groundwater of upper stratigraphic units and surface waters of these watersheds (Table 1). These 
elevated species are likely due to land use activities on the agricultural landscape in these and surrounding watersheds and are similar in concentration to levels found in a regional nitrate investigation of southeastern Minnesota (Runkel et al., 2013). No water samples were collected for anion analysis for the Campbell Valley trace.

Analytical results of water collected for these investigations verify the presence of anthropogenic signatures from land use in groundwater in this geologic setting. In southeastern Minnesota, wells open to the Prairie du Chien Group are more than twice as likely to yield water with a nitrate concentration above $2 \mathrm{ppm}$ (30.3 percent) than are wells open only to the Jordan Sandstone (12.3 percent) (Runkel et al., 2013).

The marked difference in nitrate concentrations of the Prairie du Chien and the Jordan is attributed to the ability of the lower Oneota to retard nitrate-enriched water downward into the Jordan. However, near the edges of the Prairie du Chien plateau, groundwater moves rapidly downward through enhanced fractures in the Prairie du Chien until it encounters the basal Jordan Sandstone (Figure 7). From there, lateral flow across the basal Jordan resurges as springs in incised valleys that form the headwaters of many creeks. The nitrate concentrations of these headwater streams are elevated above background conditions.

In incised valley settings, rapid vertical flow in a "stair step" like pattern appears to continue through formations underlying the Jordan, with sinking streams identified in both the St. Lawrence and Lone Rock Formations (Figure 7). Groundwater emerging from springs progressively deeper in the geologic section show mixing of nitrate poor water from distant sources up-gradient of the incised valleys. In general, nitrate concentrations of these springs show moderately high mixed signatures or low signatures that are consistent with un-impacted groundwater.

Tritium values of groundwater collected in nearby Wabasha and Fillmore counties show that vintage water,

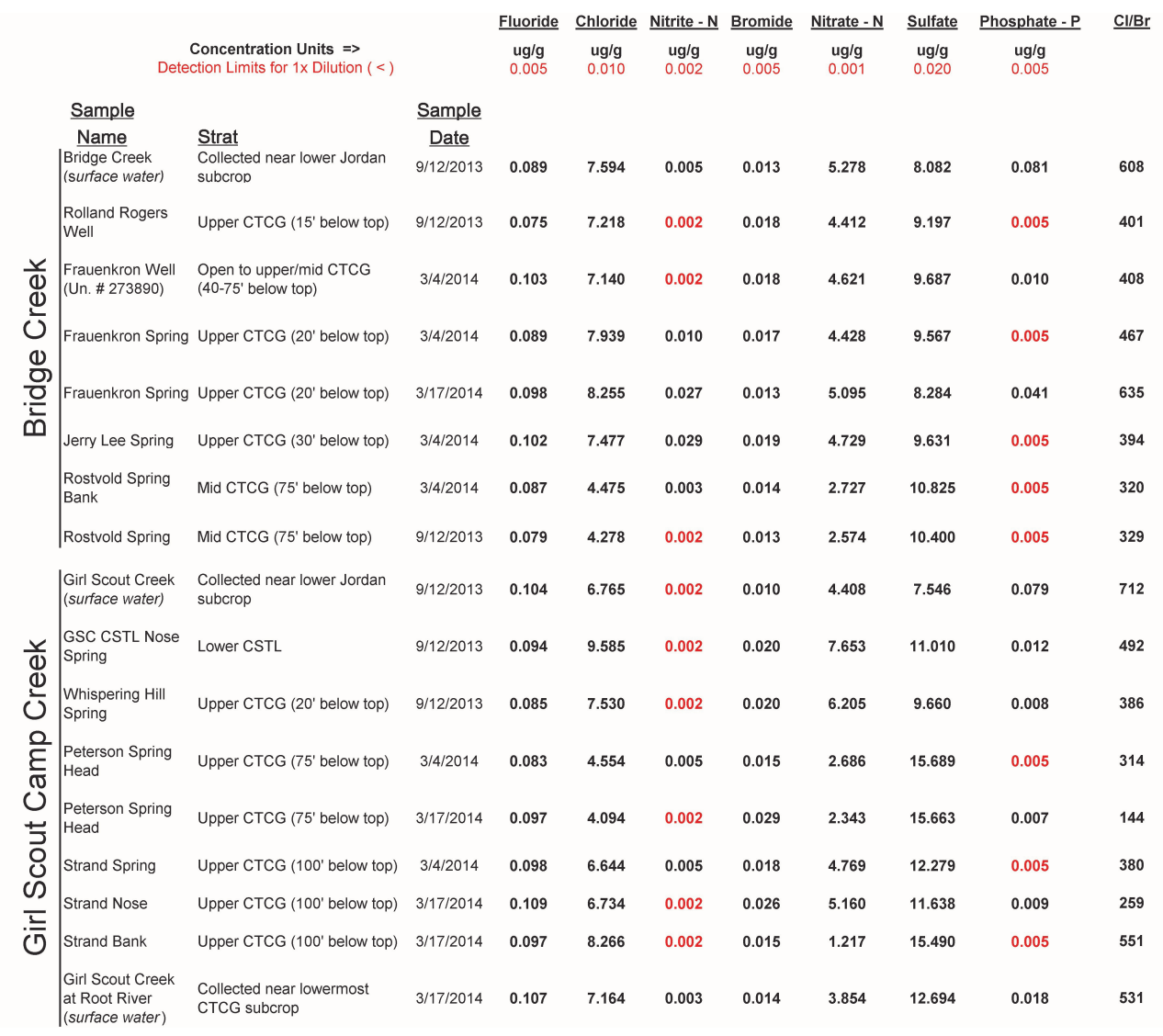

Table 1. Anion chemistry of grab samples collected in the Bridge Creek and Girl Scout Creek Watersheds. Note: $u g / g=m g / L=p p m$ 
in excess of 50 years old, generally is present underlying the St. Lawrence Formation (Petersen, 2005, Zhang and Kanivetsky, 1996). Outside of incised valley settings; the St. Lawrence impedes downward flow and acts as an aquitard.

Dye traces completed from sinking streams in the St. Lawrence and Lone Rock all show similar breakthrough curves. The curves exhibit a rapid breakthrough, rapid rise to a peak, followed by very long (months to years) tails. In February 2015, passive dye receptors were placed at springs where positive dye detection occurred for each of the traces detailed above. The receptors were in place for a two week period and recovered Uranine dye from the 2013 Bridge Creek trace at the Jerry Lee Spring and recovered dye Rhodamine WT dye from the 2013 Girl Scout Camp Creek trace at the Peterson Spring. These dyes were recovered roughly 510 days following their introduction. No dye was recovered from the Campbell Valley trace at Pagel's Power Spring.

Breakthrough curves from traces in the St. Lawrence and Lone Rock formations are fundamentally different from curves of the Galena and Prairie du Chien formations. Breakthrough curves in these karst units are generally asymmetric with rapid peaks and tails that last hours to days for the Galena and days to weeks for the Prairie du Chien (Alexander, E.C., Jr., oral commun., 2015). The groundwater velocities calculated for the Bridge Creek, Girl Scout Camp Creek, and Campbell Valley Creek traces are consistent with previous traces in the St. Lawrence and Lone Rock where peak rates range from 35 to 600 meters/day (Green et al., 2012).

The connection between surface water and groundwater found in these dye traces has human health and contaminant transport implications that are related to aquitard integrity and aquifer susceptibility in this unique setting. In incised valley settings in southeastern Minnesota, both the St. Lawrence and Lone Rock may be compromised by connectivity to surface water and the ability of water to travel at rapid rates.

\section{Conclusions}

Dye trace results, outcrop observations, water chemistry, and data gleaned from borehole geophysics demonstrate

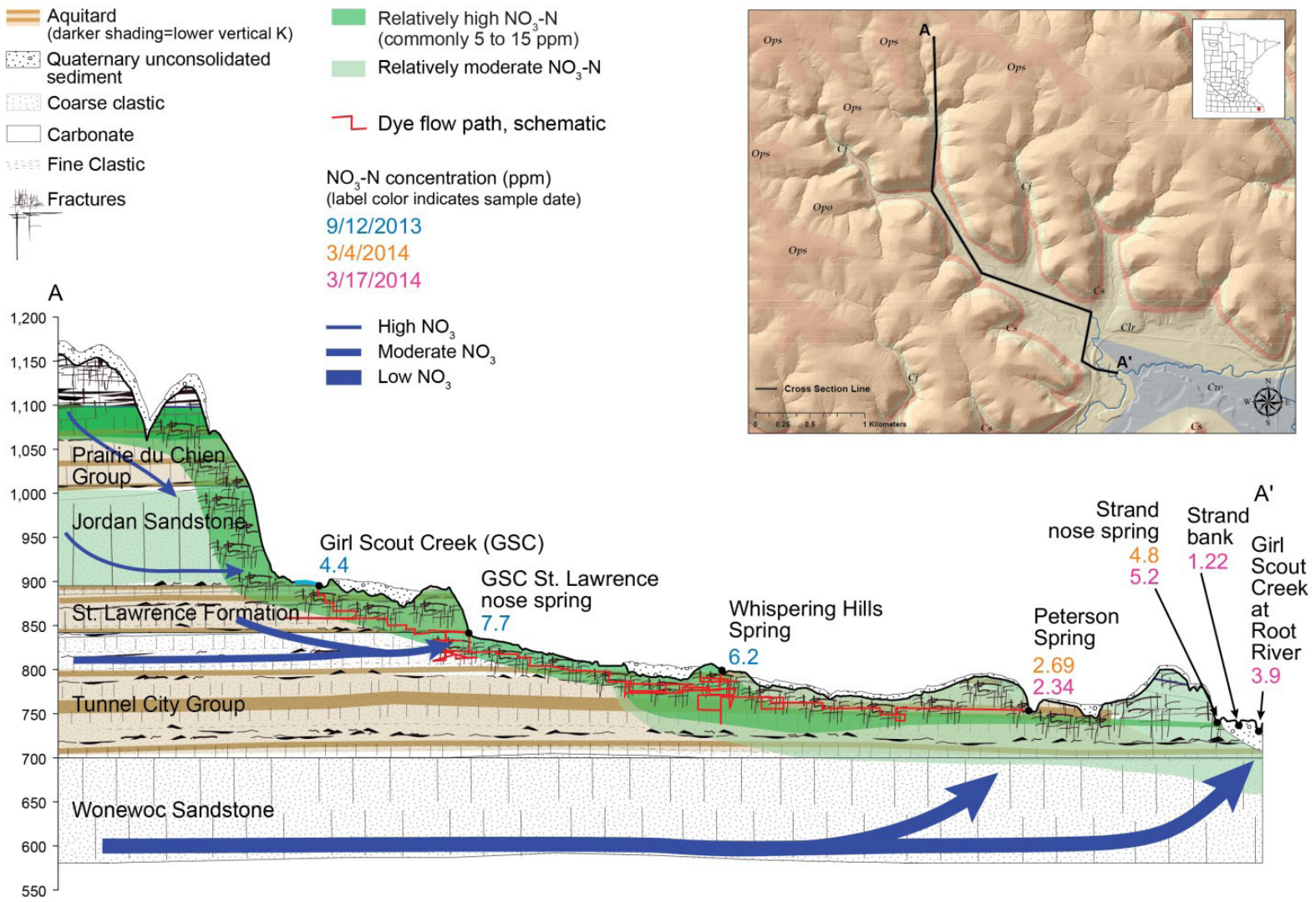

Figure 7. Cross section of the Girl Scout Camp Creek trace with surface water and spring nitrate levels. Green shading used to depict regional nitrate levels from Runkel et al., 2013. 
that the St. Lawrence and the Lone Rock have attributes of both an aquifer and an aquitard dependent upon depth of burial and landscape setting. Dye traces have shown that conduit networks throughout the St. Lawrence in incised valley settings are connected to conduit networks in the underlying Lone Rock Formation and that these networks exhibit high to very high horizontal and vertical hydraulic conductivity within the relatively low permeability rock matrix.

The conduit networks investigated here allow for rapid subsurface drainage but do not exhibit the behavior of solutionally enlarged networks common in karst (rapid rising and losing limbs on breakthrough curves). Instead, breakthrough curves for traces in the St. Lawrence and Lone Rock formations had very long losing limbs that last from months to years. This demonstrates the lack of large scale karst conduit networks and supports recent work suggesting that these features are mechanical in origin and formed very early on in the rock's history.

Hydrogeologic characterization of Houston and Winona counties will be furthered through the Department of Natural Resources portion of the County Atlas Program. Roughly 100 samples from wells and 20 from springs in each county will be collected and analyzed for cations, anions, trace metals, tritium and stable isotopes. These data will allow us to better resolve the interaction of recent and older regional groundwater, especially in the incised valleys of these counties.

\section{Acknowledgments}

The work presented in this report could not have occurred without the permission of landowners who graciously allowed access to their property. This effort was conducted as part of the Innovative Springshed Mapping for Trout Stream Management-Phase II as funded by the Minnesota Environment and Natural Resources Trust Fund as recommended by the Legislative and Citizen Commission on Minnesota Resources (LCCMR). Calvin Alexander, Jr. of the University of Minnesota Earth Sciences Department performed sample analysis and interpretation. Special thanks are given to Holly Johnson for her graphic editing assistance.

\section{References}

Alexander EC, Jr., Runkel AC, Tipping RG, Green JA. 2013. Deep time origins of sinkhole collapse failures in sewage lagoons in SE Minnesota In:
Land L, Doctor DH, Stephenson JB, editors. NCKRI Symposium 2 Proceedings of the 13th Multidisciplinary Conference on Sinkholes and the Engineering and Environmental Impacts of Karst, Carlsbad, New Mexico, published online by NCKRI, Carlsbad, NM, p. 285-292.

Alexander EC, Jr., Green JA, Alexander SC, Spong RC. 1996. Spring sheds, Plate 9. In: Lively RS, Balaban NH, editors. Geological Atlas of Fillmore County, Minnesota: Part B, County Atlas Series published by the Minnesota Department of Natural Resources.

Alexander EC, Jr., Lively RS. 1995. Karst- aquifers, caves and sinkholes. In: Lively RS, Balaban $\mathrm{NH}$, editors. Text supplement to the Geologic Atlas, Fillmore County,Minnesota: Minnesota Geological Survey County Atlas Series C-8, Part C, p. 10-18.

Anderson JR, Runkel AC, Tipping RG, Barr K, Alexander EC, Jr. 2011. Hydrostratigraphy of a fractured urban aquitard: Geological Society of America Field Guides 24, pp 457-475.

Bauer EJ, Chandler VW. 2014. Data-base map: plate 1, Geologic Atlas of Houston County, Minnesota, Minnesota Geological Survey County Atlas C-33, 4 pls. scale 1:100,000.

Davis SN, Whittemore DO, Fabryka-Martin J. 1998. Uses of chloride/bromide ratios in studies of potable water: Ground Water 36 (2): 338-350.

Green JA, Alexander EC, Jr., Marken WG, Alexander SC. 2002. Karst hydrogeomorphic units: pl. 10 of Falteisek J, editor, Geologic atlas of Mower County, Minnesota, Minnesota Department of Natural Resources, Division of Waters County Atlas C-11, pt. B, scale 1:100,000.

Green JA, Mossler JH, Alexander SC, Alexander EC, Jr. 1997. Karst hydrogeology of Le Roy Township: Mower County, Minnesota, Minnesota Geological Survey Open File Report 97-2. 2 Plates, Scale 1:24,000.

Green JA, Runkel AC, Alexander EC, Jr. 2012. Karst conduit flow in the Cambrian St Lawrence Formation, southeast Minnesota, USA. Carbonates and Evaporites 27 (2): 167-172.

Green J, Luhmann A, Peters A, Runkel A, Alexander EC, Jr, Alexander S. 2008. Dye tracing within the St Lawrence confining unit in southeastern Minnesota. In: Yuhr L, Alexander EC, Jr, Beck B, editors. Sinkholes and the Engineering and Environmental Impacts of Karst, American Society of Civil Engineers, Proceedings GSP 183, p 477-484.

Kempe S, Halliday WR. 1997. Report on the discussion on pseudokarast, in Proceedings of the 12th International Congress of Speleology, v. 6, 
Basel, Switzerland, Speleoprojects.

Klimchouk AB, Ford DC. 2000. Types of karst and evolution of hydrogeologic setting. In: Klimchouk AB, Ford DC, Palmer AN, Dreybrodt W, editors. Speleogenesis evolution of karst aquifers: Huntsville, Ala., National Speleological Society, p. 45-53.

Lusardi BA, Adams RS, Hobbs HC. 2014. Surficial Geology, plate 3, Geologic Atlas of Houston County, Minnesota, Minnesota Geological Survey County Atlas C-33, 4 pls. scale 1:100,000.

Minnesota Department of Health. 1998. Guidance for mapping nitrate in Minnesota groundwater, $20 \mathrm{p}$.

Minnesota Department of Health. 2011. Rules Handbook- A Guide to the Rules Relating to Wells and Borings, Saint Paul, MN, accessed January 21, 2015 at http://www.health.state.mn.us/divs/eh/ wells/ruleshandbook/ruleshandbook.pdf.

Mossler JH. 2008, Paleozoic stratigraphic nomenclature for Minnesota: Minnesota Geological Survey Report of Investigations 65, 76 p., 1 pl.

Panno SV, Hackley KC, Hwang HH, Greenberg SE, Krapac IG, Landsberger S, O'Kelly DJ. 2006. Characterization and Identification of $\mathrm{Na}-\mathrm{Cl}$ Sources in Ground Water. Ground Water 44 (2): 176-187.

Petersen TA. 2005. Hydrogeologic cross sections, plate 9, Geologic Atlas of Wabasha County, Minnesota, Minnesota Department of Natural Resources County Atlas C-14, 3 pls. scale $1: 100,000$.

Runkel AC, Cowan CA, Stewart ZW, Jacobson WZ. 2015. Origin of Hydraulically Significant Bed Parallel Macropore Networks in Siliciclastic Bedrock: Geological Society of America Abstracts with Programs 47 (6): 36.

Runkel AC, Tipping RR, Green JA, Jones PM, Meyer JR, Parker BL, Steenberg JR, Retzler AJ. 2014. OFR14-04, Hydrogeologic Properties of the St. Lawrence Aquitard, Southeastern Minnesota. Minnesota Geological Survey.

Runkel AC, Steenberg JR, Tipping RG, Retzler AJ. 2013. Physical hydrogeology of the groundwatersurface water system of southeastern Minnesota and geologic controls on nitrate transport and stream baseflow concentrations: Minnesota Geological Survey report delivered to the Minnesota Pollution control agency, Contract number B50858 (PRJ07522).

Runkel AC, Tipping RG, Alexander EC, Jr., Green JA, Mossler JH, Alexander SC. 2003. Hydrogeology of the Paleozoic bedrock in southeastern Minnesota. MGS Report of Investigations 61, 105 p., 1 map in pocket.

Steenberg JR. 2014a. Bedrock Geology, plate 2, Geologic Atlas of Houston County, Minnesota, Minnesota Geological Survey County Atlas C-33, 4 pls., scale 1:100,000.

Steenberg JR. 2014b. Bedrock Geology, plate 2, Geologic Atlas of Winona County, Minnesota, Minnesota Geological Survey County Atlas C-34, 4 pls., scale 1:100,000.

Stewart ZW, Cowan CA, Runkel AC. 2012. Sediment deformation in the Jordan Sandstone and influences on modern hydrogeology: Geological Society of America Abstracts with Programs 44 (7): 556.

Wilon JT. 2012. Water-quality assessment of the Cambrian-Ordovician aquifer system in the northern Midwest, United States: U.S. Geological Survey Scientific Investigations Report 2011-5229, $154 \mathrm{p}$.

Worthington SRH. 2003. A comprehensive strategy for understanding flow in carbonate aquifers. / Speleogenesis and Evolution of Karst Aquifers 1 (1), www.speleogenesis.net. 8 pages, re-published from: Palmer, AN, Palmer, MV, Sasowsky, ID. (eds.), Karst Modeling: Special Publication 5, The Karst Waters Institute, Charles Town, West Virginia (USA), 30-37.

Zhang H, Kanivetsky R. 1996. Bedrock hydrogeology, plate 6, Geologic Atlas of Fillmore County, Minnesota, Minnesota Department of Natural Resources County Atlas C-8, 4 pls. scale 1:100,000. 
